https://doi.org/10.30910/turkjans.633559

\begin{tabular}{c}
\hline TÜRK \\
TARIM ve DOĞA BiLIMLERI \\
DERGISI \\
\hline \hline
\end{tabular}

\section{Research Article}

TURKISH

JOURNAL Of AGRICULTURAL and NATURAL SCIENCES

www.dergipark.gov.tr/turkjans

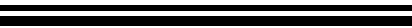

\author{
Salih DOĞAN ${ }^{1 *}$, Sibel DOĞAN ${ }^{1}$, Orhan ERMAN ${ }^{2}$ \\ ${ }^{1}$ Biology Department, Sciences and Arts Faculty, Erzincan Binali Yıldırım University, Erzincan, Turkey \\ ${ }^{2}$ Biology Department, Sciences Faculty, Fırat University, Elazığ, Turkey \\ * Corresponding author: salihdogan@erzincan.edu.tr
}

Received: 08.01.2019

Received in Revised: 03.08.2019

Accepted: 09.09.2019

\begin{abstract}
Three female mite (Acari) specimens collected from litter and soil under silverberry (Elaeagnus angustifolia) in Elazığ province, Turkey were identified as Eutogenes frater Volgin (Cheyletidae). This species shows distinct differences from other species in the genus, namely dorsal idiosoma covered by two shields, surface of the shields with papilliform granules, all dorsal setae fan-like, propodosomal shield bearing 10 pairs of setae, hysterosoma with 12 pairs of dorsal body setae. Eutogenes frater has been given before from the type locality, Bulgaria, and was later recorded from Algeria, Hungary and Iran. This species has also been known from Giza, the north of the Nile Delta (Egypt) and Burg Al Arab (United Arab Republic). Description of this species with its phase contrast and differential interference contrast (DIC) micrographs are provided here. This is the first reported occurrence of the genus Eutogenes Baker from Turkey.
\end{abstract}

Key words: Occurrence, Elazığ, Eutogenes, predatory mite, Turkey.

\title{
Eutogenes frater Volgin (Acari, Cheyletidae): Türkiye Akar Faunasının Yeni Bir Üyesi
}

\begin{abstract}
Özet
Elazığ ilinde (Türkiye) iğde (Elaeagnus angustifolia) altından alınan toprak ve döküntüden üç dişi akar (Acari) örneği, Eutogenes frater Volgin (Cheyletidae) olarak teşhis edildi. Bu tür; dorsal idiosomanın iki plak ile örtülü olması, plak yüzeylerinin papil şeklinde granüllü olması, propodosomal plağın 10 çift, histerozomal plağın 12 çift kıl taşıması ve tüm dorsal kılların yelpaze şeklinde olması gibi özellikleriyle Eutogenes cinsine dâhil olan diğer türlerden belirgin şekilde farklılıklar gösterir. Eutogenes frater, ilk olarak tip yeri olan Bulgaristan'dan tanımlanmış, daha sonra Cezayir, İran ve Macaristan'dan verilmiştir. Bu tür aynı zamanda Giza, Nil Deltası'nın kuzeyi (Mısır) ve Burc el Arab'dan (Birleşik Arap Emirlikleri) da bilinmektedir. Çalışmada, türün tanımı ile birlikte faz kontrast ve diferansiyel interferans kontrast (DIC) donanımlı mikroskopta çekilmiş fotoğrafları verilmiştir. Bu eser, Türkiye'den Eutogenes cinsinin bulunduğuna dair ilk bildirimdir.
\end{abstract}

Anahtar kelimeler: Bulunma, Elazığ, Eutogenes, predatör akar, Türkiye.

\section{Introduction}

The genus Eutogenes Baker is recognized within the family Cheyletidae by: body ovoid, two shields on propodosoma, no eyes, palp tarsus bearing two comb-like setae and two sickle-like setae, palp tibial claw toothless, leg I without claws and empodia (Volgin, 1969; Summers and Price, 1970; Corpuz-Raros, 1998; Gerson et al., 1999).
So far, 14 species in this genus have been described in the world: Eutogenes africanus Wafa and Soliman [former U.A.R.], E. bakeri CorpuzRaros [Philippines], E. citri Gerson [Israel], $E$. cornutus [Philippines], E. foxi Baker [USA (Texas)], E. frater Volgin [Bulgaria], E. makilingiensis CorpuzRaros [Philippines], E. narashinoensis Hara and Hanada, [Japan], E. onoi [Malaysia], E. pinicola 
Thewke and Enns [USA (Missouri)], E. punctatus Zaher and Soliman [former U.A.R.], $E$. quadrisetatus (Berlese) [Indonesia], E. reticularis Olivier and Theron [South Africa], E. vicinus Summers and Price [USA (California)]. Eutogenes africanus Wafa and Soliman was given as a synonym of $E$. frater Volgin by Fain and Bochkov (2001). Wafa and Soliman (1968) think that Eutogenes quadrisetatus (Berlese) belongs to Cheletogenes not to Eutogenes. Therefore, this genus currently contains 12 valid species.

A total of 18 species of the family Cheyletidae have been listed from Turkey (Erman et al., 2007; Koç, 2011; Akpınar et al., 2017). It forms a small fraction of the total cheyletid mites in the world. The genus Eutogenes Baker was not represented in Turkey, but it is now added as part of the mite fauna of Turkey, with description of Eutogenes frater Volgin based on the specimens collected from Kovancılar district, Elazığ-Turkey.

\section{Material and Methods}

Berlese-Tullgren funnels were used to extract the mite specimens. The specimens were mounted on microscopic slides in Hoyer's medium under a stereo microscope using by the standard method (Walter and Krantz, 2009). The specimens were examined and photographed by an Olympus BX63 DIC and phase-contrast microscope. The examined specimens were deposited in the Acarology Laboratory of Erzincan Binali Yıldırım University, Erzincan, Turkey. Measurements were taken in micrometers $(\mu \mathrm{m})$ using Leica Application Suite (LAS) Software Version 3.8. Mean values are followed by the range (given in parentheses). Dorsal setal and leg setal designations follow Kethley (1990) and Grandjean (1944), respectively.

\section{Results and Discussion}

Genus Eutogenes Baker

Type species: Eutogenes foxi Baker, 1949: 304 , by original designation.

\section{Eutogenes frater Volgin}

Eutogenes frater Volgin, 1958: 460.

Eutogenes africanus Wafa and Soliman, 1968: 225, syn. by Fain and Bochkov (2001).

\section{Female $(\mathbf{n}=\mathbf{3})$}

Body ovoid (Figs 1 and 2), length (excluding gnathosoma) 268 (255-284) $\mu \mathrm{m}$, width 195 (185210) $\mu \mathrm{m}$.

Length of gnathosoma 102 (98-108) $\mu \mathrm{m}$, width 83 (77-90) $\mu \mathrm{m}$ (Figs 3-5). Rostrum pointed (Fig. 4), with two pairs of adoral setae $\left(o r_{1,2}\right)$. Subcapitulum with one pair of setae $(m)$, longitudinal apodeme on midventral line of subcapitulum (Fig. 5). Anterior margin of protegmen conical, dorsal surface strongly striated, bearing two pairs horn like processes laterally. Tegmen also strongly striated. Palps short and thick. Palp tarsus with two comb-like and two sickle-like setae. Palp tibia bearing one dorsal, one ventral and one inner ventral setae, palp claw edentate. Palp genu short, with one ventral acicular seta and one dorsal lanceolate and serrate seta. Palp femur robust and elbow-like, its dorsal surface coarsely striated and punctuated, bearing one lanceolate and serrate seta and two ventral acicular setae.

Dorsum completely covered two shields (Fig. 1), surfaces of the shields ornamented with papilliform granules. Propodosomal shield 130 (127-135) $\mu \mathrm{m}$ long and 186 (170-205) $\mu \mathrm{m}$ wide, bearing six pairs of marginal setae and four pairs of median setae (Fig. 6). One pair of humeral setae situated posterolaterally, humerals similar in form to the dorsals, slightly longer than others. Eyes absent. Length of hysterosomal shield 134 (127144) $\mu \mathrm{m}$, width 165 (156-180) $\mu \mathrm{m}$, bearing eight pairs of marginal setae and four pairs of median setae (Fig. 7). Dorsal body setae squamiform, hysterosomal medians and laterals in the same shape as the propodosomal medians and laterals.

Ventral surface with striae (Fig. 2), with $1 a$, $3 a$ and $4 a$ simple intercoxal setae. Coxae in two groups, coxae I and II separated from coxae III and IV. Coxisternal shields absent. Three pairs of aggenital setae $\left(a g_{1,3}\right)$ present, two pairs close to the anogenital shields. Two pairs of genital setae $\left(g_{1,2}\right)$ and three pairs of pseudanal setae $\left(p s_{1-3}\right)$ present (Fig. 8).

Leg I 198 (192-204) $\mu \mathrm{m}$, leg II 157 (150-167) $\mu \mathrm{m}$, leg III 175 (171-182) $\mu \mathrm{m}$, leg IV 187 (179-198) $\mu \mathrm{m}$. Tarsus I lacking claws but tarsi I-III bearing them (Figs 3 and 9). Apical part of tarsus I with three long setae. Chaetotaxy of leg segments as follows: coxae 2-1-2-2, trochanters 1-1-1-1, femora 2-2-2-1, genua $2(+1 \kappa)-2-2-2$, tibiae $4(+1 \varphi)-4-4-4$, tarsi 5(+1 $\omega)-7(+1 \omega)-7-7$.

\section{Material examined}

Three females from litter and soil under Elaeagnus angustifolia, TURKEY, Elazığ, Kovancılar district, near Yazıbaşı village, 4 November 2007, coll. C. Çitil.

\section{Conclusion}

Eutogenes frater can easily be distinguished from the related species Eutogenes cornutus Corpuz-Raros by having 12 pairs of dorsal body setae on hysterosoma (11 pairs in the latter). This species shows distinct differences from other species in the genus: dorsal idiosoma covered by 
two shields, surface of the shields with papilliform granules, all dorsal setae fan-like, propodosomal shield bearing 10 pairs of setae.

Eutogenes frater was reported before from the type locality, Bulgaria, and later was recorded from Algeria, Hungary and Iran (Volgin, 1969; Fain and Bochkov, 2001; Bochkov et al., 2005; Darvishzadeh and Kamali, 2009; Ripka and Szabó, 2010, Salarzehi et al., 2018). This species was also known from Egypt and former United Arab Republic (Wafa and Soliman, 1968; Wafa et al., 1970 ) because $E$. africanus Wafa and Soliman was given as a synonym of $E$. frater by Fain and Bochkov (2001). Fain and Bochkov (2001) described homeomorphic male of Eutogenes frater, and they thought that heteromorphic male of E. africanus given by Wafa and Soliman (1968) belonged to the genus Prosocheyla.

Eutogenes frater is recorded as a new member for the Turkish fauna. This is the first report of the genus Eutogenes Baker from Turkey. The Turkish specimens exhibit the same characters as other known specimens of the species.

\section{Acknowledgment}

This work was presented as short summary at the XV International Congress of Acarology, held from September 2 to 8, 2018 in Antalya, Turkey.

\section{References}

Akpınar, D., Çobanoğlu, S. and Öğreten, A. 2017. Traits of Cheyletidae family and their usage possibilities in biological control. Turkish Journal of Agricultural and Natural Sciences, 4: 9-13. [In Turkish]

Baker, E.W. 1949. A review of the mites of the family Cheyletidae in the United States National Museum. Proceedings of the United States National Museum, 99: 267320.

Bochkov, A.V., Hakimitabar, M., Saboori, A. 2005. A review of the Iranian Cheyletidae (Acari Prostigmata). Belgian Journal of Entomology, 7: 99-109.

Corpuz-Raros, L.A. 1998. Twelve new species and one new record of Cheyletidae (Acari) from the Philippines. International Journal of Acarology, 24: 259-290.

Darvishzadeh, I., Kamali, K. 2009. Faunistic survey of mite (Acari) associated with grapevine yards in Safiabad, Khuzestan, Iran. Journal of Entomological Research, 1: 79-93.

Erman, O., Özkan, M., Ayyıldız, N., Doğan, S. 2007. Checklist of the mites (Arachnida: Acari) of Turkey. Second supplement. Zootaxa, 1532: 1-21.
Fain, A., Bochkov, A.V. 2001. A review of some cheyletid genera (Acari: Prostigmata) with descriptions of new species. Acarina, 9: 4795.

Gerson, U., Fain, A., Smiley, R.L. 1999. Further observations on the Cheyletidae (Acari), with a key to the genera of the Cheyletinae and a list of all known species in the family. Bulletin de L'institut Royal des Sciences Naturelles de Belgique, Entomologie, 69: 3586.

Grandjean, F. 1994. Observations sur les acariens de la famille des Stigmaeidae. Archives des Sciences Physiques et Naturelles, 26: 103131.

Kethley, J. 1990. Acariformes, Prostigmata. “In: Soil Biology Guide. (ed) Dindal, D.L., Wiley, New York, pp. 667-756.

Koç, K. 2011. Three new records of cheyletid mites from Turkey (Acari: Cheyletidae). Zoology in the Middle East, 52: 126-128.

Ripka, G., Szabó, Á. 2010. Additional data to the knowledge of the mite fauna of Hungary (Acari: Mesostigmata, Prostigmata and Astigmata). Acta Phytopathologica et Entomologica Hungarica, 45: 373-381.

Salarzehi S., Hajizadeh, J., Hakimitabar, M., Ueckermann, E.A. 2018. A contribution to the knowledge of cheyletid mites of Iran with redescription of Eucheyletia flabellifera (Michael, 1878) (Prostigmata: Cheyletidae). Acarologia, 58: 457-470.

Summers, F.M., Price, D.W. 1970. Review of the mite family Cheyletidae. University of California Publications in Entomology, 61: 1153.

Volgin, V.I. 1969. Acarina of the Family Cheyletidae of the World. Akademia Nauk, Leningrad, USSR, pp. 432 (in Russian). Translated by Rao, P.M. (1987) Amerind Publishing Co., New Delhi, pp. 532 (in English).

Wafa, A.K., Soliman, Z.R. 1968. Five genera of family Cheyletidae (Acarina) in the U.A.R. with a description of four new species. Acarologia, 10: 220-229.

Wafa, A.K., Zaher, M.A., Soliman, Z.R. 1970. Lifehistory of the predator mite Eutogenes africanus Wafa and Soliman (Acarina: Cheyletidae). Bulletin de la Société entomologique d'Égypte, 54: 129-131.

Walter, D.E, Krantz, G. 2009. Collecting, Rearing, and Preparing Specimens. "In: A manual of Acarology, $3^{\text {rd }}$. (eds) Krantz, G.W. and Walter, D.E. Texas Tech University Press, Lubbock, 83-96. 
Türk Tarım ve Doğa Bilimleri Dergisi 6(4): 685-695, 2019

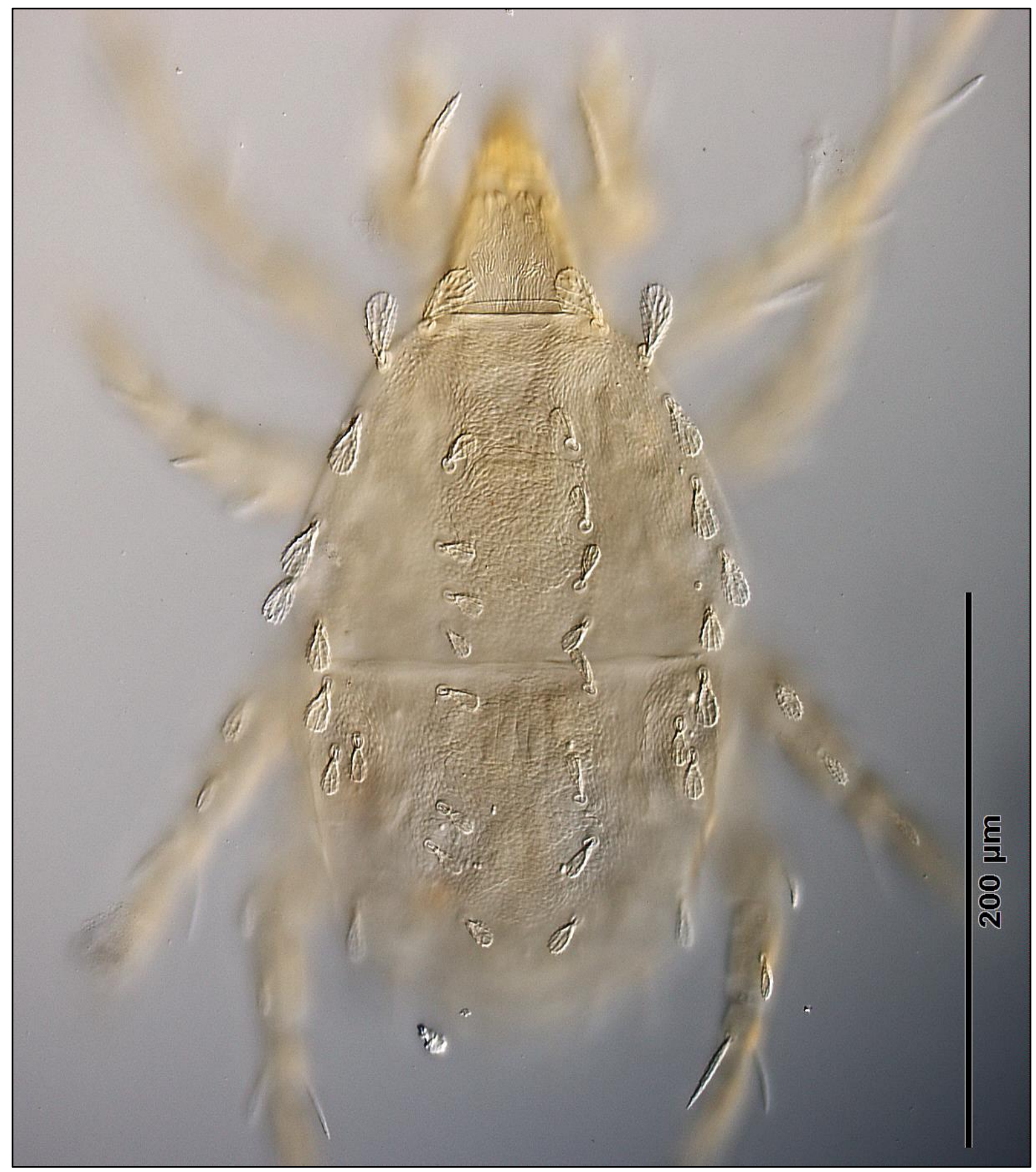

Figure 1. DIC micrograph of Eutogenes frater Volgin (Female) - General view dorsally. 
Türk Tarım ve Doğa Bilimleri Dergisi 6(4): 685-695, 2019

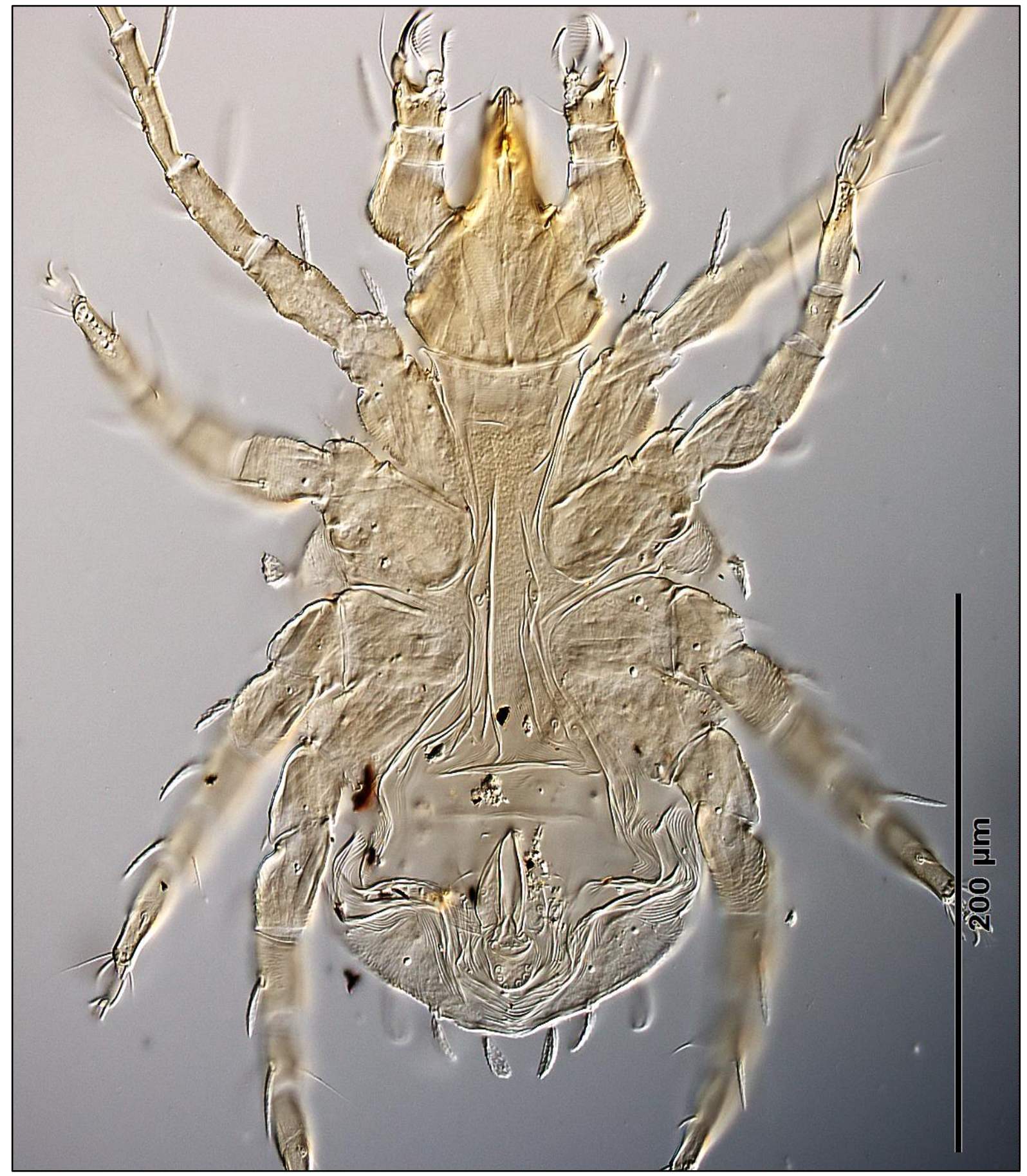

Figure 2. DIC micrograph of Eutogenes frater Volgin (Female) - General view ventrally. 


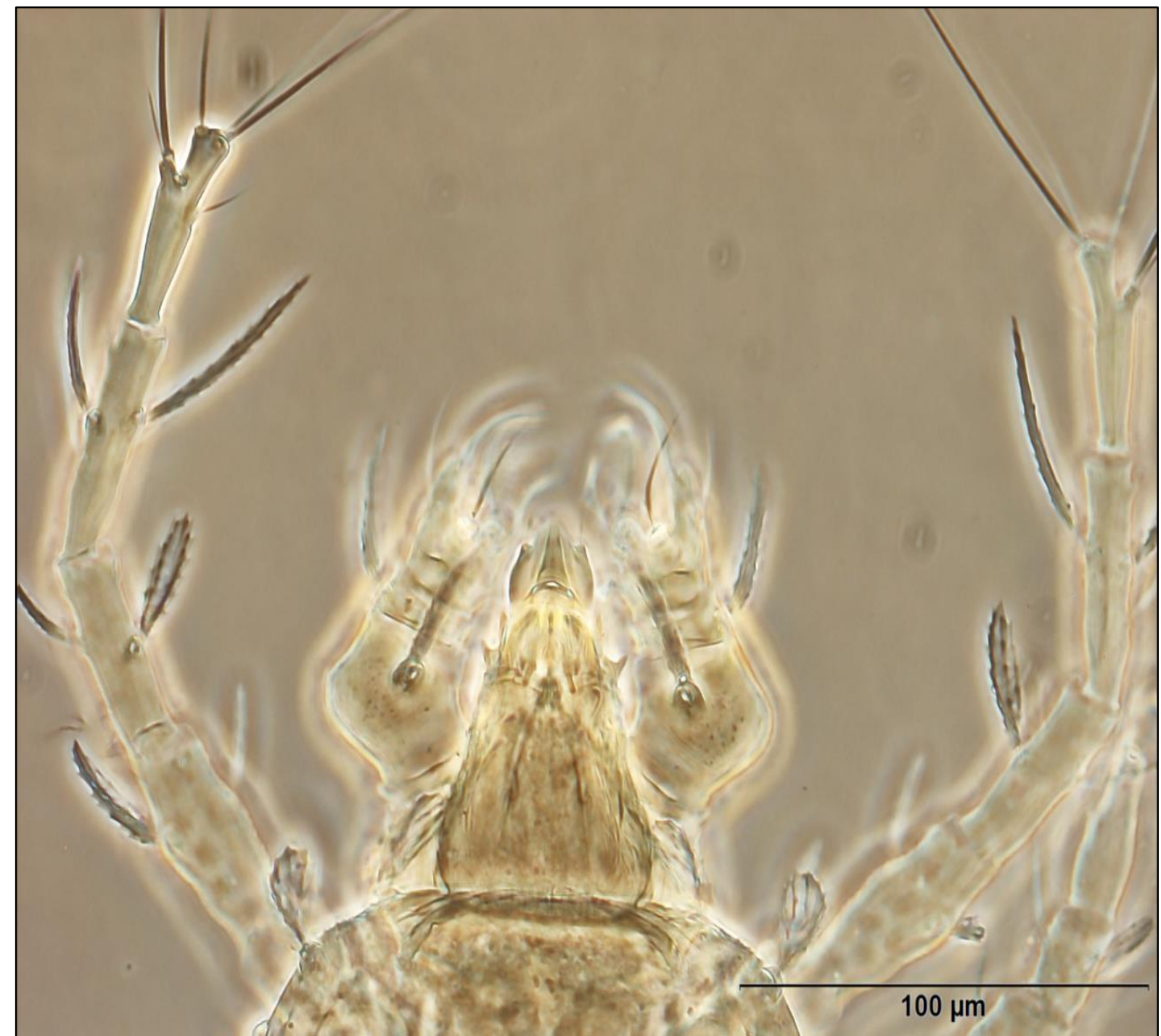

Figure 3. Phase-contrast micrograph of Eutogenes frater Volgin (Female) - Anterior part of the body in dorsal view: gnathosoma and leg I. 


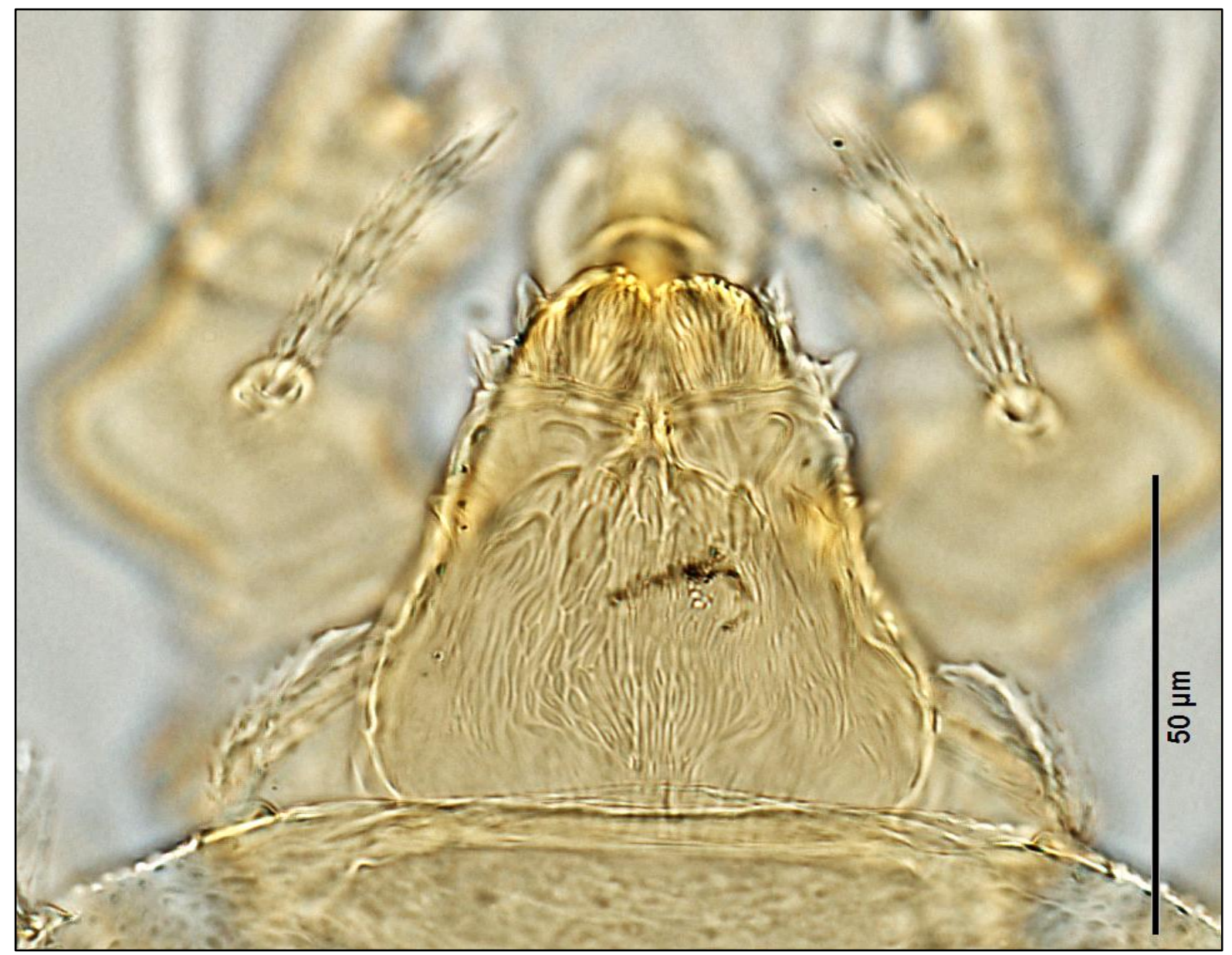

Figure 4. DIC micrograph of Eutogenes frater Volgin (Female) - Gnathosoma in dorsal view.

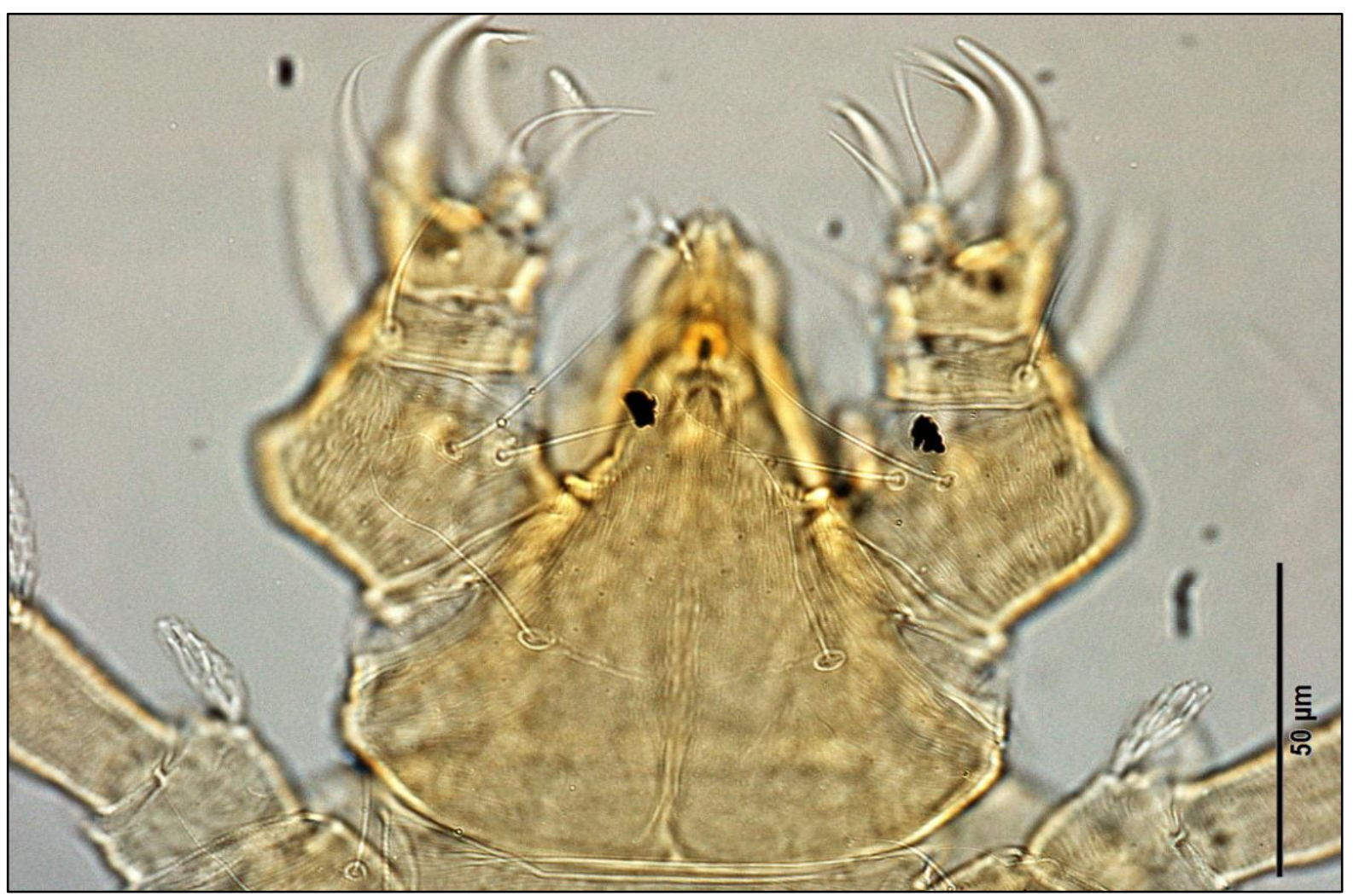

Figure 5. DIC micrograph of Eutogenes frater Volgin (Female) - Gnathosoma in ventral view. 


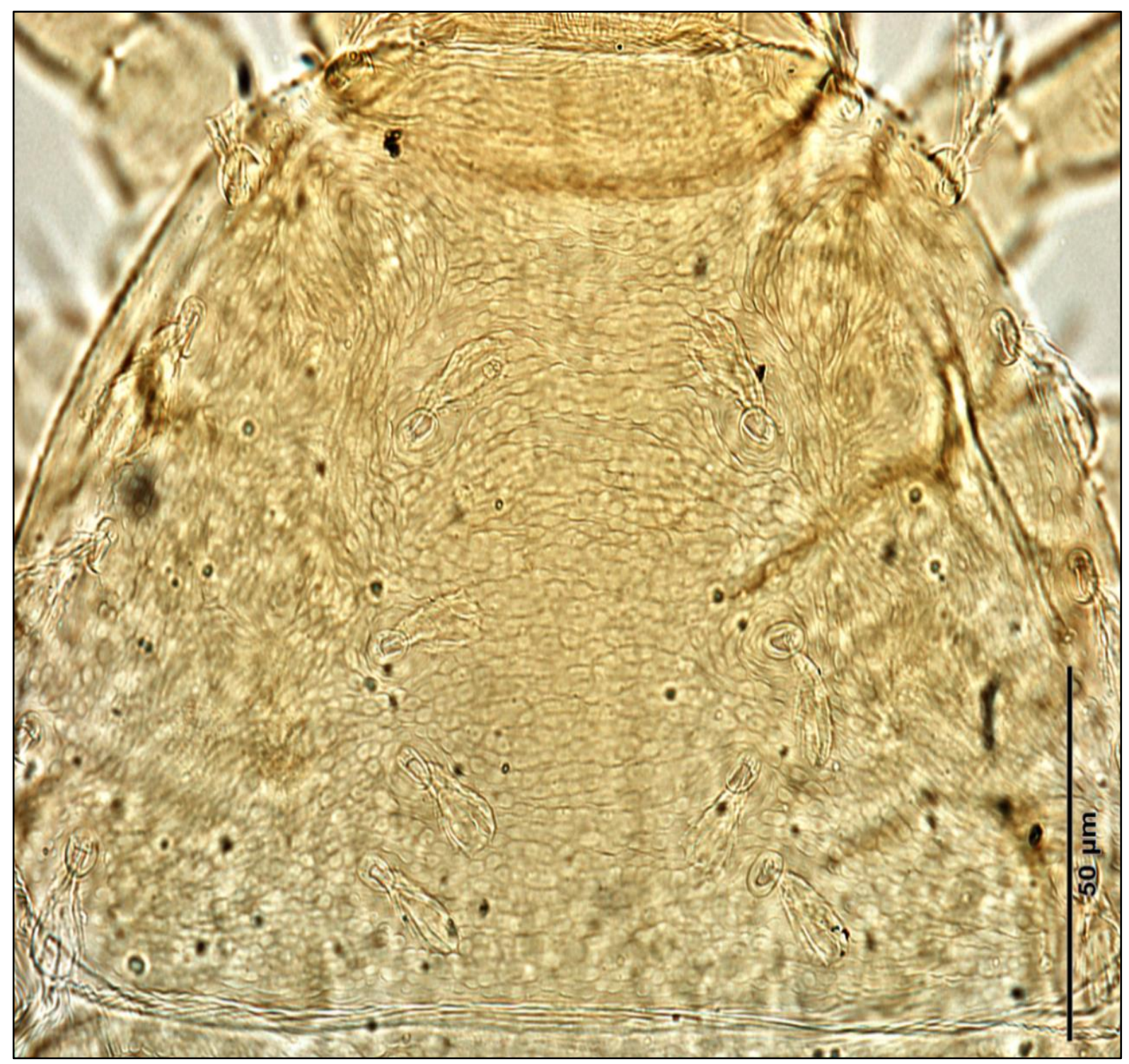

Figure 6. DIC micrograph of Eutogenes frater Volgin (Female) - Propodosomal shield. 


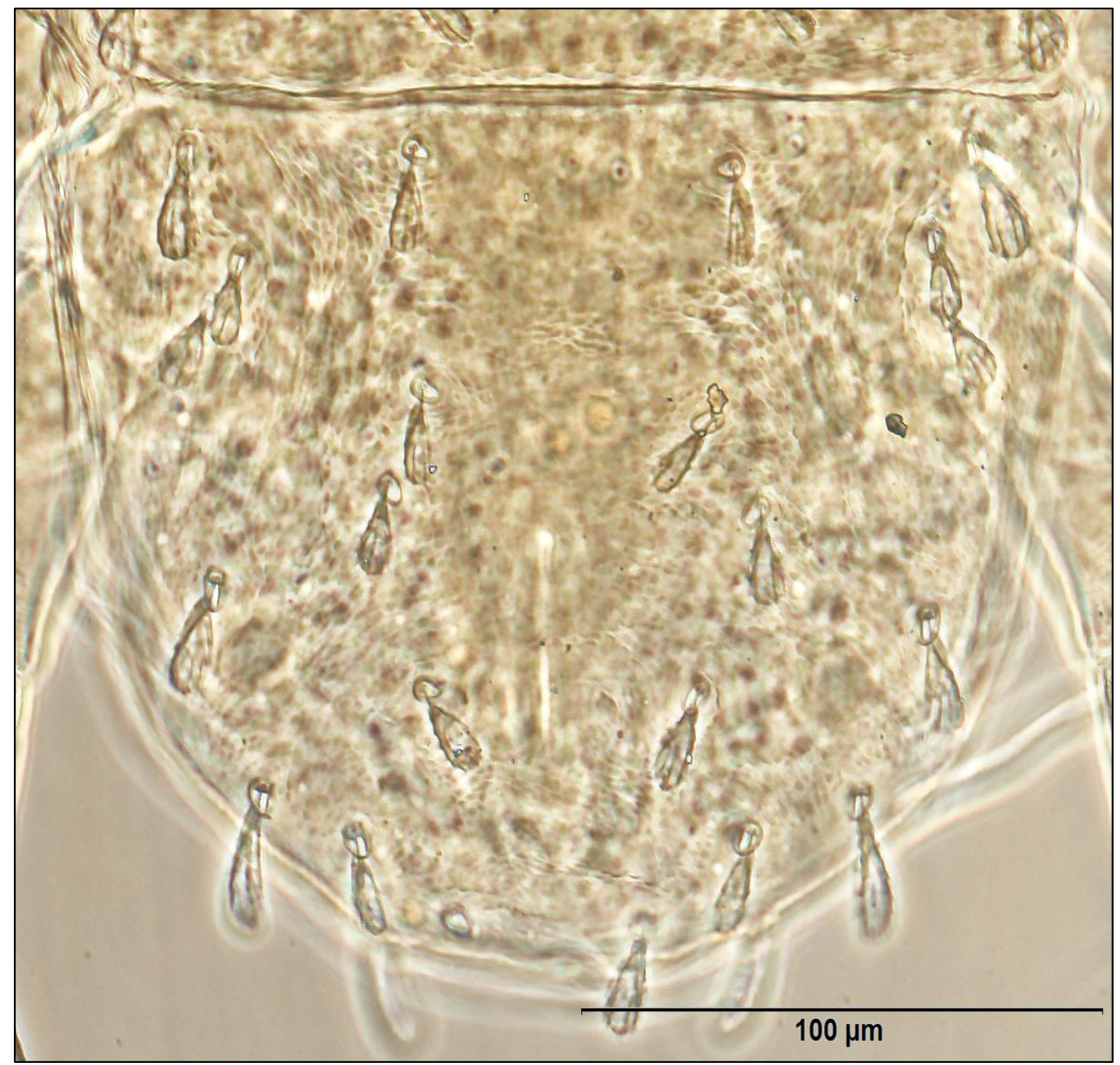

Figure 7. Phase-contrast micrograph of Eutogenes frater Volgin (Female) - Hysterosomal shield. 
Türk Tarım ve Doğa Bilimleri Dergisi 6(4): 685-695, 2019

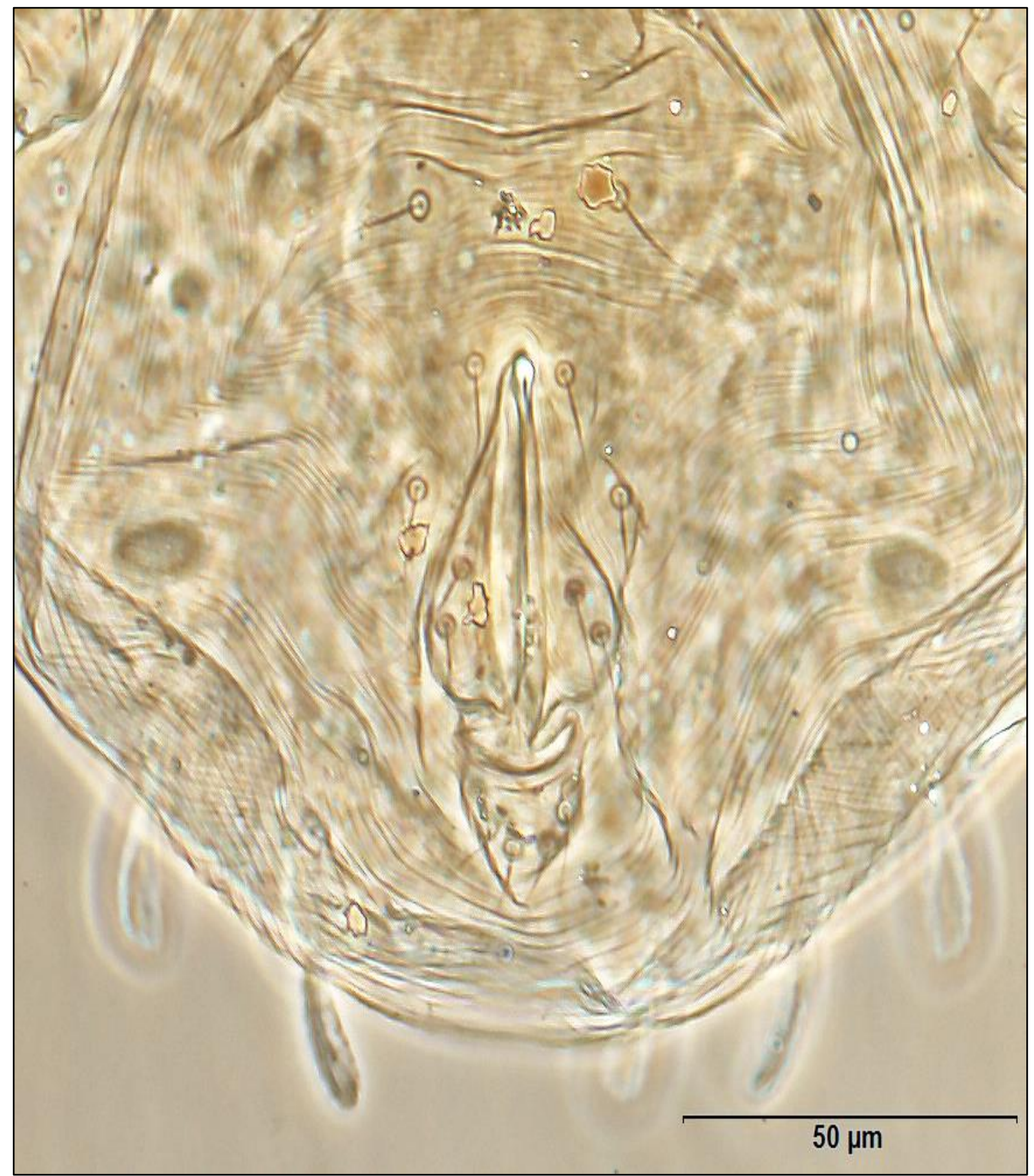

Figure 8. Phase-contrast micrograph of Eutogenes frater Volgin (Female) - Anogenital region. 


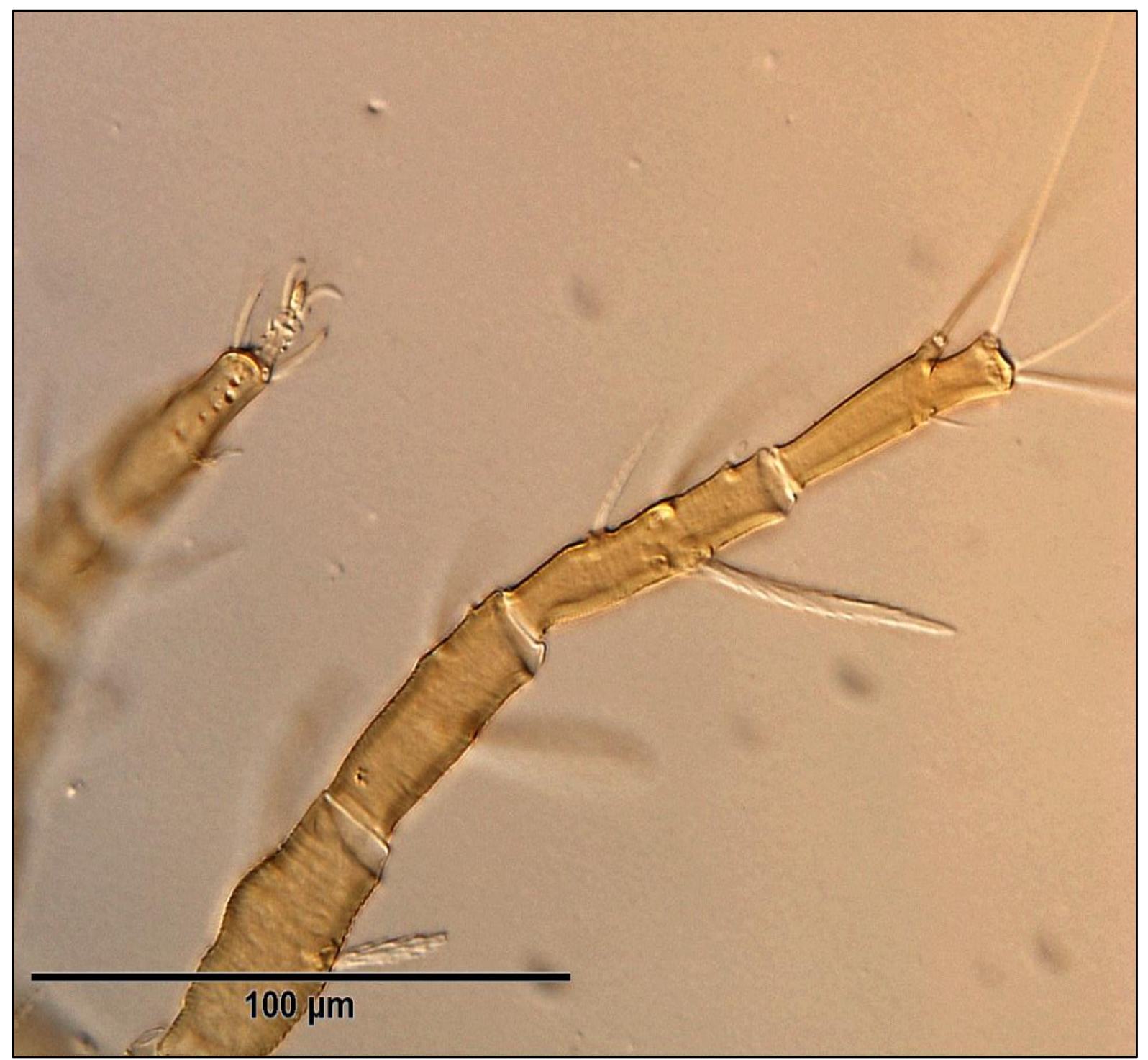

Figure 9. Bright-field micrograph of Eutogenes frater Volgin (Female) - Legs I and II. 